\title{
The Importance of Developing Indonesian Language Learning Materials Based on Local Culture for BIPA Students
}

\author{
Heny Subandiyah \\ Universitas Negeri Surabaya \\ Surabaya, Indonesia \\ henysubandiyah@unesa.ac.id
}

\author{
Bambang Yulianto \\ Universitas Negeri Surabaya \\ Surabaya, Indonesia \\ bambangyulianto@unesa.ac.id
}

\author{
Kisyani Laksono \\ Universitas Negeri Surabaya \\ Surabaya, Indonesia \\ kisyani@unesa.ac.id
}

\begin{abstract}
There are many factors to determine the successful learning. One of the factor is the appropriate learning material. The foreign university students of Bahasa Indonesia in Unesa need the appropriate learning material that suit with their learning target. That are, skilfull in Bahasa (Indonesian language) and know culture in Indonesia. However, the learning material that provides in the classroom only focuses on the language skill, especially, it happens in Unesa. It provides the language knowledge and skill of Bahasa only. Which involved giving attention, speaking, reading, and writing. It has not involved acquaintance of culture in Indonesia. It consists of chapter which is arranged based on skill aspect not based on theme. Therefore, the learning material should be develop in order to help students learn Bahasa and know the diversity and uniqueness of culture in Indonesia. In this present study, the learning materials in the form of book which is completed the media, the exercises, and the evaluations within many themes of culture in Indonesia. It is also need that foreign university students of Bahasa need to be acquainted with culture in Indonesia to increase their knowledge and interest in learning of culture in Indonesia. This study is developmental study, used Thiagaranjan [1974] model, which consisted of four steps; define, design, develop, and disseminate. The results of this study could be useful for the lecturer and foreign speaker of Indonesian language for foreign speaker or BIPA (Bahasa Indonesia untuk Penutur Asing) in Unesa.
\end{abstract}

Keywords-developmental research; learning material; thematic; local culture; BIPA

\section{INTRODUCTION}

Education determines the quality of life in nation, so that many kinds of efforts to increase the quality of education in Indonesia are carried out which is declared on Indonesian curriculum. By using the Indonesian curriculum, it is hoped the institution apply the learning program effectively.
Therefore, it can be effective when it provides the great infrastructure, media, and the appropriate learning material.

BIPA (Indonesian Language for Foreign Speaker) is one of the institution with handling the foreign university students of Bahasa. This institution exists in some of universities in Indonesia and other country. BIPA's program in Indonesia based on the enthusiasm of foreign learners to learn Bahasa or Indonesian language. The results of many survey explained that Bahasa includes in one of the favourite language which foreign learners want to know more.

In Indonesia, BIPA spreads in many universities, it is about 46-59 universities involved in, such as; Universitas Indonesia (UI), Universitas Gadjah Mada (UGM), Universitas Airlangga (Unair), Universitas Negeri Yogjakarta (UNY), and Universitas Negeri Surabaya (Unesa). In others country, BIPA exists in 45 coutries and the implementation through Education Atase or Indonesia Embassy (Kedutaan Besar Republik Indonesia). In some universities abroad, the study program of Bahasa has been opened and there is an incresment of many people abroad.

In Unesa, the implementation of BIPA program is trusted to the lecturers of Bahasa study program, English language study program, and art, drama, dance, and music (Sendratasik) study program. Then, the instructor is the lecturers who has background of languages education and arts. The crucial problem in the teaching of Bahasa for BIPA in Unesa is it has not provided the appropriate learning materials. Hence, it is essential thing to gain the learning target. Those are (1) skillful in using Bahasa for speaking or writing, and (2) knowledgeable of the culture diversity in Indonesia.

The researchers had done the observation and interview the students of BIPA in Unesa. The results showed: (1) the learning materials has provided, but the lecturers are still difficult in delivering the materials, (2) the learning materials only help the students skilful in language, but they luck of culture in Indonesia, (3) the learning materials is in the form of aspect of language themes and separated. Then, the researchers also has conducted need analysis study of learning materials by given the questionnaires for 30 foreign students. 
They are the students who studying Bahasa in Tianjin Foreign Studies University (TFSU),Tiongkok. The results showed that they need a modul or book of learning Bahasa.

Based on the explanation of background, the results of observation, interview, need analysis study, this present study is conducted to produce the learning materials in thematic roles, based on local culture, and it could be used by foreign students who has raised the proficiency of Bahasa in lever 2 (moderate). Furthermore, the reason of this developmental study is as educators, we are demanded to be able to design the learning materials creatively that could help students to use the sources [1]. In the thematic learning materials the lecturers should involve in the learning process, so that they are trained to trace the knowledge they want (learning by doing), and also knowing the local culture diversity.

Based on the problem, the purposes of this study are (1) to develop and produce the thematic learning materials based on local culture, (2) to describe the quality of learning materials that is developed to foreign students in BIPA Unesa who has 2 level in Bahasa proficiency.

The results of this study are hope to be useful for some audiences, those are:

1. For the lecturers

a. It can be used for the prominent materials to create the lesson plan (RPS) and classroom implementation.

b. It can be used for the complementary material for foreign students, especially for the outdoor activities.

2. For the foreign students of BIPA

a. It can be used to be primary sources to get the knowledge of Bahasa and culture in Indonesia.

b. It can be used to be primary sources to received the language skill.

3. For the society

The society, especially Indonesia observer in outside of Unesa, could be used the learning materials as the materials for gaining the the knowledge and skill in Bahasa, and also acquainted with culture in Indonesia.

\section{A. Learning Materials}

The learning material is a set of materials or topics which is prepared for students in the learning process. In other words, learning materials are all printed and non-printed materials, which are used by teachers and students to learn certain topic.

The printed learning materials are in the form of textbooks, papers, articles, tables, pictures, and statistical data such as diagrams or charts. Non-printed materials are in the form of electronics materials such as radio, laptop, TV, DVD, LCD, cell phones, internet networks, and others. These various nonprinting equipment could be classified as learning media. This is based on the fact that those tools help the learning process run well, so that it makes it easier for students to gain knowledge and language skills.

This learning material is expected to increasing students' motivation in learning. It is expected that students could finish one or more basic competencies using this learning material. Therefore, the learning materials should mirror the basic competencies that will be reached by students, and be presented in good language, interesting, and complete with illustrations [1]. Basic competence is manifested in the form of themes.

Well-designed of learning materials will produce a good quality of learning so that they can train students 'concentration power, create fun learning, invite students to create creative imagination, and systematically motivate students' critical thinking [7].

\section{B. The thematic learning}

Thematic learning is learning that integrates various competencies in one theme. In Indonesia, thematic learning is generally carried out in elementary schools by adding integrated words. That is, in each class learning is carried out by integrating several subjects into one theme. This integrative thematic approach is chosen because it could help students get the knowledge and language skill completely. It is hoped to create a meaningful learning for students. Integrated thematic learning is structured based on various integration processes, namely intra-disciplinary, inter-disciplinary, multidisciplinary, and trans-disciplinary integration.

Integrative thematic learning is chosen based on the philosophy of constructivism which holds that the knowledge possessed by learners is the result of the students themselves. Learners shape their knowledge through interaction with the environment, not the given of others. To get the complete knowledge and skill, the process of formation should take place continuously. Therefore, in the implementation of these thematic, learners must be actively involved in the learning process so that they are trained to find their own desired knowledge (learning by doing).

\section{The components of the learning materials}

The preparation of these teaching materials follows the components put forward by the National Education Standards Agency (2006), namely: (1) Components of content eligibility; (2) The feasibility component of the presentation; (3) Language eligibility component; and (4) Components of eligibility for graphics.

The development of learning materials uses the following principles: (1) Relevance, which is a principle that is tied the learning materials with the achievement of competency standards and basic competencies; (2) the principle of consistency, that is, the principle focuses on demands consistence; and (3) the principle of adequacy, The principle focuses on the appropriate materials that is needed in learning process.

\section{MethoDS}

\section{A. Method and Procedures}

This research uses a qualitative-descriptive approach. According to Creswell's and Brannen [4] [6], qualitative design is more focused on narratives and data descriptions. In this case, the data analysis presented in narrative- 
descriptive. The aims of this study are to develop and produce a product in the form of textbooks. This study refers to developmental research.

Developmental research theory refers to the theory of Thiagarajan [5]. The research steps are carried out through four stages, which include: (1) Define, (2) Design, (3) Develop, and (4) Disseminate. The defining stage is a stage for defining learning requirements. This defining stage includes five main steps, namely front-end analysis, student analysis, task analysis, concept analysis, and specifying instructional objectives.

The design stage is the stage that aims to design the learning materials. Four steps are taken at this stage, namely: (1) criterion-test construction, (2) media selection based on the characteristics of the material and learning objectives, (3) format selection, that is reviewing the formats of existing teaching materials and determining the format of teaching materials to be developed, (4) making an initial design based on to the formation that has been chosen.

The development phase is the research phase that aimed to produce the development products. After the products are produced, the researchers conduct the following activities (1) getting the score by an expert appraisal that is followed by a revision, (2) examining the results of development (developmental testing). The purpose of this development stage is to produce the final form of learning materials.

Dissemination stage is the final stage of development. The aim of this stage is to promote the product that is expected to be accepted by users, whether individuals, groups, or systems. According to Thiagarajan [5], "the terminal stages of final packaging, diffusion, and adoption are most important although most frequently overlooked." Producers and distributors have to be selective and work together to package the material in the right form. This stage is not done by researchers because of time constraints, especially for the costs.

\section{B. Data collection}

The data of this study were obtained by techniques: (1) observation, (2) interviews, (3) questionnaires, and (4) validation. Observations, interviews, and questionnaires were conducted at an early stage to obtain the importance data of this study. The questionnaire is an efficient data collection technique, if the researcher knows with certainty the variables that will be measured and can be expected from the respondents [2]. Validation is used to measure the validity of the results of learning material. Validation is carried out by a team of experts, namely from the teacher as a learning expert and from the lecturer as a material expert.

To measure the achievement of learning products quality, criteria based on the opinion of Nieveen [3] are used, namely validity, practicality and effectiveness. The validity of learning products in this study is based on the results of validation. The validators of this study were lecturers of language and literature of Bahasa study program. The practicality criteria are based on the implementation of learning materials, which are obtained from the teacher. The effectiveness criteria are based on mastery learning and students responses after using learning materials.

Data collection instruments in this study include: (1) observation sheet; (2) interview guidelines, (3) questionnaire sheets, and (4) validation sheets.

\section{RESULTS AND DISCUSSION}

\section{A. The results analysis of defining stage}

In the initial development process (define stage), researchers got the results of a needs analysis about the importance of preparing teaching materials in the form of books. In the questionnaire distribution phase, researchers involved 30 foreign students. The following information is need analysis of data.

a. There is a relationship between textbooks and the language skills of foreign students who are studying Bahasa.

b. Students who answered strongly agreed $0.64 \%$, those who answered agreed $9.60 \%$, those who answered neutral $0 \%$, and those who answered disagreed $0 \%$, and those who answered strongly disagreed $0 \%$.

Here are the results of the analysis in the form of a chart.

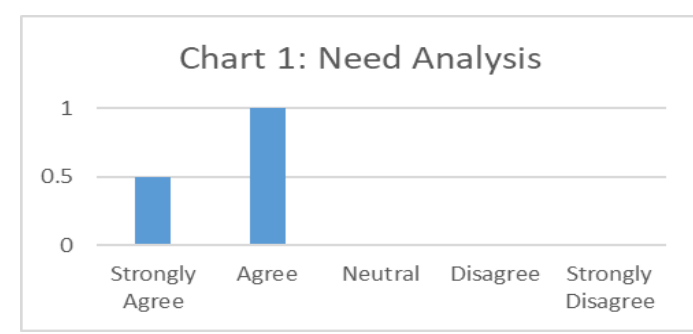

\section{B. The Design stage}

The results of the first step were followed up with the preparation of thematic textbook designs based on local culture. The design of textbooks are prepared with regard to themes based on local culture, both in the form of daily life and in the form of literature or culture. From various studies, the design of this textbook was organized as follows.

Theme 1: Meeting on the New Campus (campus introduction)

Theme 2: About MOS (introduction of new student culture)

Theme 3: Get to know Fable Stories (introduction to folklore)

Theme 4: Conversation at the Indonesian Embassy (introduction to Indonesian ways)

Theme 5: Conversation on an Airplane (introduction of flight mood)

Theme 6: Conversation at the Airport (airport introduction)

Theme 7: Call a Friend (introduction to how to call)

Theme 8: Regional songs (introduction to local culture)

Theme 9: Lebaran Homecoming (introduction to homecoming culture) 
Theme 10: Get to know the legend story (introduction to folklore)

\section{Development Phase}

Based on the design of the book, the researchers continued the development process, namely writing in detail from ten themes into ten chapters. Development is carried out by dividing each theme into sub-themes. The development of this sub-theme is based on language activities which include four language skills. The activities of reading, speaking, listening and writing are presented in an integrated manner in one chapter. Cultural introduction is done through the type of reading presented in each theme or chapter.

In each chapter linguistic knowledge is also taught. Knowledge of phonology (pronunciation), morphology (grammar and types of words), syntax (sentence structure), new vocabulary, and paragraphs, presented in an integrated manner with the activities of four language skills.

In addition, in the development process also note the addition of learning media in the form of pictures, tables, charts/charts, which are adjusted to the theme in each chapter. Various descriptions and choices of learning media are taken from relevant sources.

The results of this development phase are in the form of textbooks that are ready to print with the title Thematic-Based Indonesian Language Learning and Local Culture. This book is organized in accordance with the requirements of the contents of the book as seen in the table of contents. The book also comes with an attractive cover and introduction and table of contents at the front, as well as a bibliography at the end. This book is not final, it still needs inputs to be revised. This book is awaiting the assessment of learning experts and material experts, those are teachers and lecturers.

\section{CONCLUSION}

Based on the results of this study, it was concluded that:

1. Development of learning materials has been done but is still in the process of finalization, awaiting an assessment from the expert team to revise various deficiencies.

2. Teaching materials resulting from this development also require limited trials, namely to foreign students as users.

3. The results of the development of this teaching material are covered with the title: Thematic Based Indonesian Language Learning and Local Culture for foreign students who have Indonesian language skills level 2 (intermediate level)

4. Similar research is needed for foreign students who have level 1 (basic level) and level 3 (high level) in Bahasa proficiency.

5. Book printing has been done but is still waiting for the process of getting ISBN and IPR.

\section{REFERENCES}

[1] A. Prastowo, 2011. Metode Penelitian Kualitatif dalam Perspektif Rancangan Penelitian, Yogyakarta: Ar-Ruzz Media, 2011.

[2] Sugiyono, Metode Penelitian Administrasi dilengkapi dengan Metode R\&D, Bandung: Alfabeta, 2005.

[3] N. Nieveen, Prototyping to Research Product Qulity. Jan van den Akken et all (ed), London: Kluwer Academic Publisher, 1999.

[4] J. Creswell, Qualitative Inquiry \& Research Design: Choosing Among Five Approaches, 2nd ed, California: Sage Publication, 2007.

[5] S. Thiagarajan, D. S. Semmel, and M. I. Semmel, Instructional Development for Training Teachers of Expectional Children, Minneapolis, Minnesota: Leadership Training Institute/Special Education, University of Minnesota, 1974.

[6] J. Brannen, Memadu Metode Penelitian Kualitatif dan Kuantitatif, Yogyakarta: Pustaka Pelajar, 2005.

[7] T. deJong, Terry et.al, "The Efficacy of Simulation as a Pedagogy in Facilitating Pre-Service Teachers' Learning About Emotional Self-Regulation and its Relevance to the Teaching Profession", Australian Journal of Teacher Education: Vol. 37: Iss. 3, Article 4 2012. 